\title{
Suffering, Salvation, and the Filipino: \\ Francis Schüssler Fiorenza's Theology \\ of Divine Emancipatory Solidarity \\ in the Context of Poverty and Marginalization
}

\author{
MICHAEL DEMETRIUS H. ASIS
}

ATENEO DE MANILA UNIVERSITY, PHILIPPINES

\begin{abstract}
Francis Schüssler Fiorenza's "emancipatory solidarity" theory is here proposed as the framework for an alternative Filipino soteriology that focuses not on the Cross as sole salvific event, but on Christ's life, ministry, death, and resurrection in its entirety as key to human redemption in its fullness, including both the physical and spiritual dimensions. In contrast to the concept of redemption as the mere alleviation of suffering, this paper suggests an alternative interpretation of the Filipino virtue of fortitude in the face of suffering as in itself constitutive of a redemptive religious moment and experience.
\end{abstract}

Key terms atonement, emancipatory solidarity, popular religious piety, fortitude, death of Christ 
Lor as by one man's disobedience many were made
sinners, so by one man's obedience many will be made righteous. By his obedience unto death, Jesus accomplished the substitution of the suffering Servant who makes himself an offering for sin, when he bore the sin of many, and who shall make many to be accounted righteous, for he shall bear their iniquities. Jesus atoned for our faults and made satisfaction for our sins to the Father. ${ }^{1}$

Thus did the Church, from the very beginning of its biblical and catechetical literature, articulate the meaning and significance of Christ's death on the cross. Christ died "to be the expiation for our sins" (1 Jn. 4:10) "in accordance with the scriptures" (1 Cor. 15:3), that is, "to give his life as a ransom for many" (Mt. 20:28).

Why did Jesus die? Here lies perhaps the most important and critical theological question in relation to Christianity's claim to Christ's universal significance. That he was executed can be explained in fairly socio-political terms as the inevitable end to the kind of battles he waged. But in the greater scheme of things, what is the deeper religious meaning of his death? Is it a form of ransom necessary to pay for the debt incurred by the sins of humanity? Is it because, according to a widely held belief in Israel, the death of a just man atones for the sins of the land? ${ }^{2}$ Or is the death of

\footnotetext{
${ }^{1}$ Episcopal Commission on Catechesis and Catholic Education (ECCCE), Catechism of the Catholic Church (Vatican: Libreria Editrice Vaticana, 1994; repr., Manila: Word \&Life Publications, 1994), no. 615.

${ }^{2}$ A well-known example of this idea appears in Deutero-Isaiah 42, 49, 50, and 52, where the servant becomes an instrument of divine redemption through his suffering and death. In the New Testament, Jesus himself was often identified with this Old Testament image of "the Servant of the Lord" (Mt. 8:17; 12:18-21; Lk. 22:37; Acts 3:13, 26; 4:27, 30). This image in Second Isaiah is clearly evident in 1 Pt. 2:22-25: "He committed no sin . . He himself bore our sins in his body on the cross . . . by his wounds you have been healed." See Richard P. McBrien, Catholicism, rev. and enl. 3rd ed. (New York: Harper Collins Publishers, 1994; repr., London: Geoffrey Chapman, 2000), 444.
} 
Jesus existentially redemptive insofar as it demonstrates the degree of commitment necessary toward achieving an authentic humanity?

But if Christ's sufferings were the payment for our sins, to whom was the payment made? And why should the payment be exacted in such a violent manner? How can one person be humanity's scapegoat, taking the place of the rest for their sins? ${ }^{3}$

In current Western theology, soteriological theories focusing on expiation, satisfaction, and sacrifice have been greatly criticized. Lisa Cahill summarizes this rather pessimistic theological trend criticizing the expiation theories:

In the view of modern critics, the paradigm of Jesus' death as atoning sacrifice, especially if seen as penal substitution, seems to compromise God's mercy, to make God demand and even engineer innocent suffering, and to make a suffering death the entire purpose of the incarnation. It sets up violence as divinely sanctioned and encourages human beings to imitate or submit to it. ${ }^{4}$

The atonement paradigm, in effect, turns God into an object of terror, and calls into question divine justice, or even reason. It is incompatible with the loving and compassionate God that Jesus faithfully preached. How could such a concept, then, be truly Christian?5

The sacrificial and propitiatory language of scripture and Church catechetical tradition holds sway in popular Filipino religiosity. As Beltran points out, this perspective is "still powerful in the Filipino context because it corresponds to the people's religious expectations. It is fundamental to the Filipino religious experience."'6

\footnotetext{
${ }^{3}$ Benigno P. Beltran, The Christology of the Inarticulate: An Inquiry into the Filipino Understanding of Jesus the Christ (Manila: Divine Word Publications, 1987), 96.

${ }^{4}$ Lisa Sowle Cahill, "Quaestio Disputata The Atonement Paradigm: Does It Still Have Explanatory Value?” Theological Studies 68 (2007): 419.

${ }^{5}$ Robert J. Daly, "Images of God and the Imitation of God: Problems with Atonement," Theological Studies 68 (2001): 41.

${ }^{6}$ Beltran, Christology of the Inarticulate, 96-97.
} 
Hence, certain questions relative to a genuine scriptural hermeneutics, in general, and to a specifically Filipino soteriology, in particular, can be raised: Can the language of sacrifice, expiation, and punishment do justice to the God that Jesus proclaimed in the Gospels? If , according to popular Filipino religious imagination, redemption holds that Christ appeased a wrathful God, or that Jesus was punished in our place, wouldn't this concept of a punitive God have become a ready instrument for the subjugation of the Filipino people by their colonial masters? Does the monstrous view of God who cries for the blood of the innocent to appease his wrath help Filipinos overcome their brand of fatalism, which consigns everything to fate and the divine will, including the structural roots of their poverty and oppression? ${ }^{7}$ And how does one, in the first place, even begin to talk about suffering and salvation in the concrete context of widespread poverty and the dehumanizing destitution of many Filipinos, which in many ways constitute a blatant violation of human dignity, and hence, ultimately of God's will? ${ }^{8}$ These and many other crucial questions that challenge the classical theories of redemption, taken to be self-evident for centuries, make it all the more urgent to explore alternative discourses on atonement and redemption. This paper is one such modest attempt.

This essay begins with a brief discussion of popular Filipino views on the meaning of Jesus's death on the cross, consistent with classical theories of atonement. Do such theories really shape Filipino fatalism and reinforce passivity in the face of suffering? What does salvation mean in a context of abject poverty and marginalization? Can the classical soteriological literature still be a credible apologetic under those conditions? On the other hand, should redemption always include liberation of the whole

\footnotetext{
${ }^{7}$ Ibid., 97-98.

${ }^{8}$ See Catholic Bishops' Conference of the Philippines (CBCP), The Acts and Decrees of the Second Plenary Council of the Philippines (Manila: CBCP Secretariat, 1992), nos. 122-25.
} 
person-spiritual and physical? Can't the virtues of forbearance and fortitude in the face of suffering have an intrinsic redemptive value? These are just some of the important questions that are addressed in this first part of the study.

The second section gives an overview of classic theories of atonement, focusing on existentialist Christological models, which serve as background to Fiorenza's soteriological model. The third section introduces Francis Schüssler Fiorenza's theory of "emancipatory solidarity," here presented as a response to the shortcomings of the other models. This part of the essay demonstrates how Fiorenza's understanding of salvation in terms of solidarity provides a more encompassing concept of human redemption in its fullness.

Finally, the essay compares Fiorenza's Christology with Filipino Christologies, discussing similarities and contrasts between Filipino views of redemption and Fiorenza's emancipatory solidarity. Particular attention is devoted to exploring the Christology of popular nineteenth century peasant movements and the Katipuneros through Rafael C. Ileto's Pasyon and Revolution, ${ }^{10}$ by reinterpreting popular Christ images in the light of Fiorenza's Christology and arguing that the former can be understood as exemplifications of the latter. The essay ends by suggesting a positive retrieval of a Filipino perspective that views fortitude in the face of suffering as in itself constitutive of a redemptive moment and experience.

\footnotetext{
${ }^{9}$ This paper is inspired by my reading of Fiorenza's survey and critique of existential and transcendental approaches to atonement and redemption, and summarizes the key points in his article "Redemption" in The New Dictionary of Theology, ed. Joseph A. Komonchak, Mary Collins, and Dermot A. Lane (Pasay City: St. Paul Publications, 1991), 845-48, and in his "Critical Social Theory and Christology: Toward an Understanding of Atonement and Redemption as Emancipatory Solidarity," Proceedings of the Catholic Theological Society of America 30 (1975): 63-110. Professor Fiorenza is the Charles Chauncey Stillman Professor of Roman Catholic Studies at Harvard Divinity School in Cambridge, Massachusetts.

${ }_{10}$ Reynaldo C. Ileto, Pasyon and Revolution: Popular Movements in the Philippines, 1840-1910 (Quezon City: Ateneo de Manila Press, 1979). The Pasyon — a popular Filipino Catholic devotionare native accounts of Christ's life, death, and resurrection chanted during Lent.
} 


\section{Popular Views on the Meaning and Implications of Christ's Suffering}

More than the Child Jesus (the Santo Niño), perhaps the Filipino Christ is pre-eminently the Crucified One. Beaten, scourged, humiliated, and defeated, he suffers in the place of others, for the sake of others. The favorite images of Christ represent some episode of his Passion (the carrying of the cross, the flogging at the column, the crowning with thorns). ${ }^{11}$ In many places in the Philippines, devotees express solidarity with the Suffering Christ by flagellating themselves during Holy Week, or kissing the feet of the entombed Christ (the Sto. Entierro) on Fridays, or engaging in a frenzied mass procession carrying the image of the Black Nazarene. ${ }^{12}$ The devotion to these images speaks of quiet suffering in the face of persecution and terrible human ordeals, and manifests the Filipino's admirable fortitude in the face of trial and adversity. The kundiman, for instance, which are native songs about wounded love, ${ }^{13}$ describe the sense of inner strength and self-sacrificing love that abandons itself completely to fate or the divine will in the face of inevitable suffering.

Benigno Beltran, in his ground-breaking book, The Christology of the Inarticulate: An Inquiry into the Filipino Understanding of Jesus the Christ, articulates clearly the context of this fixation on the sufferings of Christ. He writes:

In a country where poverty, deprivation and oppression are the common lot of the masses, where typhoons and earthquakes frequently occur, it is not surprising that the

${ }^{11}$ See Frank Lynch, "Organized Religion," Area Handbook of the Philippines, vol. 2, 485, cited in Douglas J. Elwood and Patricia L. Magdamo, Christ in Philippine Context (Quezon City: New Day Publishers, 1971), 6.

${ }^{12}$ Elwood and Magdamo, Christ in Philippine Context, 6. Cf. ECCCE, Catechism for Filipino Catholics (Manila: Word \& Life Publications, 1997), nos. 467-68

${ }^{13}$ See ECCCE, Catechism for Filipino Catholics, no. 39. 
image of the Crucified One, head bowed, mouth agape in excruciating agony, provides consolation and an outlet for pent-up emotions of sympathy and tragedy for the ignorant and the heavy-laden. ${ }^{14}$

The Filipino Christ incidentally takes after the Christ of Spanish popular faith, whose distinguishing marks are essentially "a profound sense of tragedy, a terrible dread of death, and a religious fervor that dwells, sometimes morbidly, on the wounds and agony of Christ." 15 This collective sense of anguish and pathos relates, no doubt, to the long experience of oppression by the Spanish people who, from A.D. 711 to 1492, were under occupation by the Moors. ${ }^{16}$

As a form of popular faith and piety, the Filipino devotion to the Suffering Christ, however, has been criticized for being much too privatistic. Tibay ng loob (courage, inner strength), pakikiramay (empathy), and pagtitimpi (restraint) —all virtues associated with the Crucified Christstill remain simply on the personal and interpersonal levels. Given the social conditions of untold suffering in the Philippines, a social consciousness is never developed when there is an excessive sentimentalism focused on the suffering and death of Christ. "The cult of images," Beltran observes, "can easily become instrumentalized. It can evolve into a form of idolatry when it becomes an end in itself and is used to legitimize oppression and passivity in the face of injustice."17 How many of those, for instance, who inflict violence on others have been unwittingly

\footnotetext{
${ }^{14}$ Beltran, The Christology of the Inarticulate, 123.

${ }^{15}$ Elwood and Magdamo, Christ in Philippine Context, 2.

16 Ibid.

${ }^{17}$ Beltran, The Christology of the Inarticulate, 135. Local passion narratives, however, that were given a more liberationist interpretation have been instrumental in inspiring the birth of peasant resistance movements. As mentioned earlier, this is the subject of Ileto's well-known study about how the Pasyon provided 19th-century lowland Tagalog movements with a language for articulating their own values and ideals, particularly in view of their hopes for social emancipation and political liberation. See Jose Mario C. Francisco, "Christian Symbols and Rituals in Philippine Society," Pulso 7 (June 1991): 16. See Ileto, Pasyon and Revolution, 11-12. A more detailed treatment of how images and symbols of popular piety-particularly the passion narratives - can become instruments of social and political conscientization appears in the final section of this paper.
} 
influenced by a salvation theory about a God who demands the blood of the innocent as recompense for humanity's transgressions? How many wars have been waged, prisoners executed, spouses and children abused largely as a result of a perception that God tolerates violence-imposes it, in fact, when necessary-as a means of salvation?

The fixation on suffering as pagtitiis (forbearance), it would seem, while potentially cathartic, could lend credence to the charge that religion-like a mind-altering narcotic_-simply numbs consciousness to human suffering. Does this kind of soteriology, then, help give true consolation to the suffering masses in the face of their unspeakable misery, or does it simply provide a coping mechanism that, while temporarily relieving their sorrows, merely perpetuates their unjust condition? Is a wife who absorbs spousal abuse supposed to feel good when told that her pagtitiis and pagtitimpi will merit her a reward in the life beyond? Doesn't this approach to atonement and redemption continue to infantilize the faith of the Filipino Catholic by not allowing it to grow beyond an ethic much too obsessed with the pursuit of individual salvation in the afterlife, while not recognizing the many manifestations of salvation in this one. On the other hand, isn't the total acceptance of suffering in complete submission to God's will, and the forbearance required to endure it (the way countless pious Filipino Catholics have lived their faith with fortitude through the centuries), not itself a potentially genuine experience of redemption? Need salvation be always the alleviation, and not simply the endurance, of suffering?

\section{Soteriological Paradigms}

\section{The Pauline Paradigm and Atonement Models}

A diversity of interpretations can be gathered from the New Testament regarding the meaning of Jesus's death. For instance, Paul, who is perhaps the most prolific and imaginative of early theologians of Christ's death, ${ }^{18}$ interpreted Jesus's death using categories from Jewish cult, juridic thought,

\footnotetext{
${ }^{18}$ Cahill, The Atonement Paradigm, 418.
} 
as well as Hellenistic mystery religions and Gnostic myths. ${ }^{19}$ Johannine theology, on the other hand, sees not the Cross, but the incarnation of the Son in the world and his return to the Father as that which is essentially salvific. Jesus's death is but a means, however important, towards the exaltation of the Son of Man. ${ }^{20}$

Theological reflection in Church history likewise reveals a variety of soteriological understandings of Jesus's death, attempting to articulate its meaning and significance in terms of atonement and redemption. Three fundamental atonement theories have been put forward in Christian thought: (1) the ransom theory; (2) the satisfaction or substitutionary atonement theory; and (3) the moral influence or exemplary atonement theory.

A specific model of salvation, associated with Anselm of Canterbury (d. 1109) has become the dominant soteriological model in the West since the eleventh century, despite the variety of biblical theologies of salvation. "This is the model of Christ's death as a substitutionary sacrifice for human sin, needed to repay a debt to God, whose infinite honor has been offended past the limit of any purely human act of compensation."21

\footnotetext{
${ }^{19}$ See Rudolf Bultmann, Theology of the New Testament, trans. K. Grobel (New York: Charles Scribner's Sons, 1951), 292-306. Cf. Joseph A. Fitzmyer, "Pauline Theology," in The New Jerome Biblical Commentary, 2nd ed., ed. Raymond E. Brown, Joseph A. Fitzmyer, and Roland E. Murphy (Quezon City: Claretian Publications, 1993), 82:24-80, 1388-1402.

${ }^{20}$ See Werner Kümmel, The Theology of the New Testament, trans. J. E. Steely (New YorkNashville: Abingdon Press, 1973), 298. Cf. Francis J. Moloney, "Johannine Theology," The New Jerome Biblical Commentary, 83:27-40, 1421-1423.

${ }^{21}$ Cahill, The Atonement Paradigm, 419. Doubtless the most dominant interpretation of Jesus's death since the Middle Ages, this satisfaction theory proposed by Anselm of Canterbury holds that the order in the universe which was disturbed by sin could only be restored if sufficient satisfaction were offered to God. Only a divine person like Jesus could adequately compensate for the cosmic effects of Adam's fault. And so he who was sinless endured death as a voluntary payment for sin, taking our place and offering a ransom of "satisfaction" to God for the insult of sin. See McBrien, Catholicism, 297, 482. Cf. Fiorenza, "Redemption,", 842. Cf. David Van Biema, "Why Did Jesus Die?" Time, April 12, 2004, 42. The exemplarity theory of redemption, on the other hand, advanced by the French medieval theologian Peter Abelard (d. 1142), focused less on Jesus's death as recompense for the forgiveness of humanity's sin than as the exemplification of a life of perfect love. Jesus's fundamental moral commitment of love that reveals God's loving presence evokes in human beings a response of love that not only becomes the basis for forgiveness, but ultimately overcomes humanity's alienation from God. It is ultimately his life, not his death in itself, which can save us. See Fiorenza, "Redemption," 842-43. Cf. Van Biema, "Why Did Jesus Die?" 45.
} 
Modern theology, for its part, moves between subjective and objective interpretations of Jesus's death as atonement and redemption. Subjective soteriological interpretations of the Cross find the classical theories of redemption insufficient insofar as atonement was understood in light of such categories as representation, substitution, satisfaction, and propitiation. "Guilt and sin are individual," argues Francis Schüssler Fiorenza, "and cannot be transferred. Redemption is both an effect and cause of personal influence." 22 Objective theories of redemption, on the other hand, find the subjective theories much too focused on individualism and hardly appreciative of the social aspects of personal sin, guilt, and human nature itself. ${ }^{23}$

Notwithstanding the wealth of diversity with respect to soteriological interpretations of Jesus's death, modern theology has laid greater emphasis on his death, often at the expense of the much broader dimensions of redemption and the traditional elements thereof. Focusing on the death of Jesus as the pivotal point of understanding redemption often overlooks the salvific value of his entire life: his teaching and bold proclamation of God's Rule, his healings and miracles that indicated God's Reign already breaking into history, and his prophetic clash with evil in the form of oppressive power and domination.

This emphasis on Jesus's death as constitutive of human redemption is due in large measure to the existentialist trend in much of modern theology, and is perpetuated by the reaction to this trend.

\section{The Existentialist Influence ${ }^{24}$}

Karl Rahner sees Jesus's death as his act of radical self-donation and self-acceptance expressive of the meaning and significance of both his divinity and humanity. Central to his soteriology is Jesus's death as an

${ }^{22}$ Fiorenza, "Redemption," 849.

23 Ibid.

${ }^{24}$ Two theologians of the twentieth century who recognize their indebtedness to the existential philosophy of Martin Heidegger are Karl Rahner and Rudolf Bultmann. See Fiorenza, "Critical Social Theory and Christology," 67-68. 
act of personal realization. The very mode of God's Self-disclosure is manifested through God's Word (Logos). This divine Self-communication reaches its highpoint in the Self-emptying act of the Logos incarnate to precisely express the nature of God as love. ${ }^{25}$ This divine Self-giving in love manifests itself fully in the death of Jesus. Being both divine and human, Jesus's death realizes God's totally unconditional Self-giving to the world as well as the unequivocal human response to it. ${ }^{26}$

While Rahner criticizes classic soteriology for failing to take serious account of Jesus's human activity and life, he assigns to Jesus's death an almost primordial and absolute meaning-effecting God's universal salvific will through Jesus's voluntary obedience and surrender to God. As a result, Rahner has reservations about how the other acts of Jesus's life could have salvific value. ${ }^{27}$ But does not the redemptive activity of Jesus involve his entire life, a life that inevitably led to his execution? Furthermore, given Rahner's own acknowledgment of the threat of any form of death in all of human experience (oppression, infirmity, misery, suffering, and the like), would Jesus himself not have faced all threats to human life and well-being? Isn't the human drive for solidarity and the creation and protection of life, then, an equally fundamental human principle as the phenomenon of death itself? Redemption, then, should be understood as a much more comprehensive event that not only includes the confrontation with the problem of death, but also involves the redemptive power of the human desire for solidarity and new life. ${ }^{28}$

Rudolf Bultmann, the premiere New Testament scholar of the twentieth century, posits a theology of the cross that challenges the Greek and modern scientific predisposition towards self-sufficiency and the notion that self-identity and salvation are within one's power through the

\footnotetext{
${ }^{25}$ Karl Rahner, Theological Investigations, vol. 1, trans. K. Smyth (New York: Seabury, 1974), 105-20.

${ }^{26}$ Karl Rahner, "Salvation," in Sacramentum Mundi, vol. 2 (New York: Herder and Herder, 1970), $430 \mathrm{ff}$.

${ }^{27}$ Fiorenza, "Redemption," 845-46.

${ }^{28}$ See Fiorenza, "Critical Social Theory and Christology," 72.
} 
discovery of knowledge. ${ }^{29}$ Driven by overconfidence in the power of reason and human effort, this worldview finds its negation in the scandal of the cross which dismisses as pure illusion the ability to control one's future. Only in taking on a new self-understanding and through God's grace can we move towards an authentic kind of existence. ${ }^{30}$

While Bultmann's position provides an insightful look into the relation between human frailty and divine grace, his contrast between human effort and divine grace appears excessive. ${ }^{31}$ While Bultmann shares Rahner's opinion that Jesus's death as propitiatory sacrifice is insufficient a theory in interpreting the cross, both confine the locus of redemption to the death of Jesus. The life and message of Jesus is appreciated only in view of his death. Human existence should be viewed not only in terms of its limit situations, especially the finality of death, but more holistically to include the creative imperative of affirming life in the socio-political order. ${ }^{32}$

\section{Critique of the Existentialist Appropriation}

Wolfhart Pannenberg criticizes Bultmann for his characteristically salvific approach to Christology, an approach that is vulnerable to both subjective reductionism and Feuerbach's critique of religion as mere projection of the human spirit in the concept of God. ${ }^{33}$ Pannenberg proposes an alternative approach that asserts the objective nature of Christology - a presupposition that can be questioned in many respects since it is grounded in the assumption that truth, and in this case, Christological truth, can be established a priori $^{34}$

\footnotetext{
${ }^{29}$ Rudolf Bultmann, Jesus Christ and Mythology (New York: Charles Scribner's Sons, 1958), 3544.

${ }^{30}$ See Fiorenza, "Redemption," 845.

${ }^{31}$ See Fiorenza, "Critical Social Theory and Christology," 78.

32 Ibid.

33 Ibid., 79.

34 Wolfhart Pannenberg, Jesus_God and Man, trans. L. L. Wilkins and D. A. Priebe (Philadelphia: Westminster Press, 1968), 21-48. See Fiorenza, "Critical Social Theory and Christology," 80.
} 
To forestall such criticisms, Pannenberg, makes the historical Jesus his point of departure and not the Jesus as he can be existentially engaged in the present. Pannenberg believes that Jesus's death and resurrection were events that happened to him and were not explicitly determined by his own initiative and actions. Jesus could have sensed, Pannenberg acknowledges, the fatal consequences of his radical message when he confronted the powerful elite of Jerusalem. Pannenberg, however, does not push this awareness on the part of Jesus to its logical conclusion. But since Jesus remained unequivocal about his understanding of his message, would Jesus not have known the terrible risks it involved? ${ }^{35}$

Secondly, while Pannenberg acknowledges the objective value of the cross as a form of service to others, he is not certain whether Jesus's death comes as a direct consequence of this service or a service in and of itself. Hence, Pannenberg weakens the link between Jesus's death and his conscious, active service to humanity. ${ }^{36}$

Despite Pannenberg's emphasis on the universal elements in Jesus's ministry, he disengages the death of Jesus from his life and message. Pannenberg argues, therefore, that while Jesus's fate was sealed by his revolutionary message, the significance of his death cannot be drawn from the consequential effect of his ministry. ${ }^{37}$ His death was simply the penalty endured in place of the people who deserved it, bound as they were to the authority of the law. ${ }^{38}$

Relative to Rahner and Bultmann, Pannenberg sees the significance of Jesus's death as separate from his life ministry. Given his rejection of an incarnational approach to Christology, Jesus's death, in Pannenberg's account, owes its significance not to his life but to his resurrection. ${ }^{39}$ It is his rising from the dead that invests the cross with its ultimate significance since the life of Jesus is no longer accessible to us in its original historical sense.

\footnotetext{
${ }^{35}$ See Fiorenza, "Critical Social Theory and Christology," 81.

36 Ibid.

${ }^{37}$ Ibid.

${ }^{38}$ Ibid., 82.

${ }^{39}$ Ibid., 81-82.
} 
Pannenberg criticizes the much too individualistic emphasis the penal theory of substitution puts on guilt and responsibility, but does not critically take into account the social network and presuppositions in which the same theory operated. ${ }^{40}$

In The Crucified God, ${ }^{41}$ Jürgen Moltmann's reactions to Bultmannian existentialism determine his constructive theories for a theology of the cross. Moltmann agrees with Bultmann's objections against any effort to objectify Jesus's death as a mere event of a historical past. However, Moltmann observes that Bultmann's understanding of the cross seemingly refuses to acknowledge any kind of inherent significance in Jesus's death, and that the cross can be meaningful and significant only if existentially engaged in the present. ${ }^{42}$

Going beyond the idea of the cross as expiatory sacrifice, Moltmann makes a distinctive contribution by arguing that the death of Jesus expresses the significance of the resurrection, and not the other way around. ${ }^{43}$ The proleptic vision of the resurrection is significant insofar as the one who was raised dies in our place. The resurrection, then, is not some mere future event, but a moment of love that liberates all humanity. ${ }^{44}$

In an act of utter oblation, Jesus rendered the defining moment not only for himself, but for the God he so faithfully embodied. In the death of Jesus, an intertrinitarian event that involved God and the Son, we witness God taking on the sins of the world, enduring suffering, guilt, and punishment, which a sinful humanity rightly deserved. Nowhere is God more fully God's self than in this act of humiliation, nowhere more divine than in this solidarity with a fallen humanity. What takes place in Jesus

\footnotetext{
${ }^{40}$ Ibid., 84.

${ }^{41}$ Jürgen Moltmann, The Crucified God: The Cross of Christ as the Foundation and Criticism of Christian Theology, trans. R. A. Wilson and J. Bowden (New York: Harper and Row, 1974).

${ }^{42}$ See Fiorenza, "Critical Social Theory and Christology," 84-85.

${ }^{43}$ See Fiorenza, "Redemption," 847.

${ }^{44}$ See Fiorenza, "Critical Social Theory and Christology," 85.
} 
crucified is something that happens to God's inmost self: not a death of God, but a death within God. ${ }^{45}$

God's solidarity with a sinful and suffering humanity through the death of Jesus proves to be a deeply meaningful and significant theodicy in light of the intolerable suffering of millions today. Furthermore, this theology of a suffering God provides Christianity with its distinctive identity that is neither grounded in church affiliation, creedal confession, and conversion experiences, nor in socio-political involvement for the cause of social justice. ${ }^{46}$

Moltmann's interpretation, however, raises two questions: First, by speaking of God as someone who "Himself" suffers from the evil of the world, isn't Moltmann assigning an ontological existence to evil that it should not have in the first place ${ }^{47}$ Aren't people more confident in a God who liberates them from their suffering, rather than in one who simply identifies with their predicament? Our religious symbolic language, it would seem, should meaningfully address the fundamental ambiguity of human existence.

Second, by identifying the cross as Christianity's distinguishing feature, Moltmann runs the risk of confining Christian identity to one elementnamely, its prophetic role-at the expense of equally important aspects of Christianity such as commitment to God and neighbor. ${ }^{48}$ While the prophetic implications of the cross constitute an essential element of the Christian vision, identifying it as the essential core indiscriminately rejects all other ecclesial and institutional expressions of Christian identity. ${ }^{4}$

\footnotetext{
${ }^{45}$ Jürgen Moltmann, Le Dieu crucifié: La croix du Christ, fondement et critique de la théologie chrétienne (Paris: Cerf, 1974), 232-35, cited in Louis-Marie Chauvet, Symbol and Sacrament: A Sacramental Reinterpretation of Christian Existence, trans. Patrick Madigan and Madeleine Beaumont (Collegeville, PA: Liturgical Press, 1995), 502-3. This book by Moltmann is the French translation of the German original.

${ }^{46}$ Fiorenza, "Critical Social Theory and Christology," 86.

47 Ibid., 87.

48 Ibid.

${ }^{49}$ Ibid., 87-88.
} 
Moreover, reducing the Church to its socio-political involvement makes the Church liable to be dismissed as merely one among the current ideologies in society. Christian faith and praxis should assume a more constructive, rather than purely critical, function that gives religious interests on behalf of social justice and peace concrete human expression.

In light of present socio-political realities, it is necessary to construct a theology of atonement and redemption that does not disengage the life and message of Jesus from his death, but sees his entire life as redemptive, and his death, a consequence of his lifelong commitment to God's Rule in the world. ${ }^{50}$

\section{The Theology of Emancipatory Solidarity}

\section{Critical Social Theory}

In contradistinction to the Rahnerian and Bultmannian existentialist approach with its singular focus on the cross as the locus of redemption, and to Pannenberg's objectivistic and Moltmann's speculative metaphysics, Francis Fiorenza proposes a theology of atonement of redemption based on Jürgen Habermas's critical social theory. ${ }^{51}$ Habermas's critique of an objectivistic understanding of theory and of knowledge that is detached from existential human interests and praxis leads him to a theory of understanding that is situated within a vast network of interest and application. ${ }^{52}$

Habermas particularly objects to a thoroughly behavioristic and objectivistic approach to social scientific knowledge that fails to take into account the unfolding of human understanding within the context of the interpreter's horizons. ${ }^{53}$ Given the symbolic and polyvalent nature of

${ }^{50}$ Ibid., 89.

51 Ibid., 91.

52 Ibid., 92.

${ }^{53}$ Ibid. Cf. Hans-Georg Gadamer, Truth and Method, rev. 2nd ed., trans. Joel Weinsheimer and Donald Marshall (New York: Sheed \& Ward, 1989). 
language and the intentional nature of human consciousness, one should not overlook the subjective presuppositions of the interpreting subject. ${ }^{54}$ To understand is to acknowledge multiple possibilities of meaning latent in a particular subject examined. ${ }^{55}$ It is, therefore, necessary to engage in a hermeneutical process, given the semiotic nature of language.

While it is true that the hermeneutical method is necessary in acknowledging that understanding is mediated symbolically through language and the tradition engendered by such a process, Habermas criticizes the tendency of tradition to be uncritical of its own social injustices in the form of structures of domination, such as patriarchy, among others. Tradition is certainly the very matrix of understanding as event. However, tradition is not merely a complex of linguistically articulated ideas, but also a web of patterns that may reflect certain unjust social structures. Tradition is more than that which binds us to past enlightened views. ${ }^{56}$

Habermas's theory of knowledge, together with his theory of communicative competence, calls for a theological language that is not merely linguistically competent, but performatory and pragmatic. It provides the groundwork for Fiorenza's theology of redemption as emancipatory solidarity. ${ }^{57}$ Truth assertions necessarily have practical implications. ${ }^{58}$ Over and against a more precise, univocal, and technical form of language, contemporary theology, like sciences of social action,

\footnotetext{
${ }^{54}$ Paul Ricoeur uses the term "polysemy" in reference to the intrinsic opacity and richness of language. See Don Ihde, ed., "Editor's Introduction," in The Conflict of Interpretations: Essays in Hermeneutics (Evanston: Northwestern University Press, 1974), xiv.

${ }_{55}$ See Paul Ricoeur, "Existence and Hermeneutics," trans. Kathleen McLaughlin, in The Conflict of Interpretations, 13. Cf. Paul Ricoeur, "The Problem of Double Meaning," trans. Kathleen McLaughlin, in The Conflict of Interpretations, 68-69.

${ }^{56}$ Fiorenza, "Critical Social Theory and Christology," 93.

${ }^{57}$ See ibid., 94-97. Communicative competence involves not only the ability to learn a language's abstract system of rules (linguistic competence), but also the facility for communication and the mastery of symbolic interaction. Language not only describes reality, but performs it as well. Verbs such as "promise" and "command" demonstrate this pragmatic function of language. See ibid., 94-96.

58 Ibid., 95.
} 
possesses an inherent emancipatory interest. ${ }^{59}$ Further implications for theology of Habermas's critique of social scientific knowledge include engaging in critical self-reflection and critique of ideologies uncritical of their own power structures. ${ }^{60}$

\section{Redemption as Emancipatory Solidarity}

Since there is an intrinsic nexus between theory and praxis, classical theories of atonement and redemption should be examined within the context of the symbolic network of the culture that shaped them. Our assertions of faith are always historically conditioned. ${ }^{61}$ There is in culture a multi-leveled system of connections between and among such elements as social symbols, political patterns, and diverse human interests. ${ }^{62}$ We bring our Faith to a level of conscious expression against the background, and within the matrix, of our existential questions and concerns. Hence, statements of faith should not be examined apart from their sociohistorical milieu since these are attempts to appropriate the Faith using categories of one's lived culture. There is a world not only in front of, but also behind the text. Jose de Mesa and Lode Wostyn, famous for their contextual Filipino theology, write:

People never experience salvation in the abstract, but in the context of their own life, within particular social and cultural patterns. This means that we do not have to speak about salvation in strange, "supernatural" terms; it can be put into ordinary language, the language of genuine dialogue with people and of experiences of specific liberating events. ${ }^{63}$

\footnotetext{
59 Ibid., 96.

${ }^{60}$ Ibid.

${ }^{61}$ See Roger Haight, Dynamics of Theology (New York: Paulist Press, 1990), 175-79.

${ }^{62}$ See Fiorenza, "Critical Social Theory and Christology," 98. Cf. Chauvet, Symbol and Sacrament, 84 .

${ }^{63}$ Jose M. de Mesa and Lode L. Wostyn, Doing Christology: The Re-Appropriation of a Tradition (Quezon City: Claretian Publications, 1989), 32.
} 
One should, therefore, not only determine the meaning of redemption theories formally and structurally, but also uncover the social structures and political patterns that shaped the way they are formulated. A critical hermeneutical issue that can be raised, for instance, today is whether it is still appropriate to meaningfully speak of a redeeming God in terms of patriarchal categories and patterns of sovereignty?64 While Anselm's satisfaction theory may not have originally the same divine vindictive intent that its meaning seems to carry today, still it appears theologically unintelligible, ethically incredible, and pastorally unsound-within the framework of the socio-intellectual culture in place today-to speak of a God who demands propitiation through the sacrifice of a human being.

On the other hand, while sensitivity to the metaphorical language operative in faith assertions is necessary to construct appropriate, meaningful, and significant ways of speaking about redemption today, caution should be taken in using a phenomenological approach to theories of redemption. Otherwise, our contemporary interpretations may fall to the other extreme of so disembodying Jesus from his own situated history to the extent that he loses all his distinctiveness as a historical person. ${ }^{65}$ Still, for any meaningful appropriation of redemption to take place, there is a need to re-express traditional theories in new and different forms that break and transcend traditional patterns of political sovereignty. ${ }^{66}$

It is a constructive task of theology to view the entire life of Jesus as imbued with redemptive significance. His life and message communicate the reality of redemption they signify — a solidarity with both God and humanity. ${ }^{67}$ In other words, based on the theory of communicative competence, Jesus communicated the reality of redemption through his twofold solidarity - a deep union with the Father and a profound solidarity

${ }^{64}$ See Fiorenza, "Critical Social Theory and Christology," 100-101.

${ }^{65}$ See Michael Demetrius H. Asis, "Hermeneutical Theory and the Quest for the Historical Jesus: A Study of Two Christologies," The Loyola Schools Review 1 (2001): 106.

${ }^{66}$ See Haight, Dynamics of Theology, 175-79.

${ }^{67}$ Fiorenza, "Critical Social Theory and Christology," 104-5. 
with others. This double commitment "brings to expression who Jesus is in himself." 68 Grounded on this unique understanding of himself, Jesus communicated the reality of human redemption through the language of his embodied existence-his life and his message. ${ }^{69}$ Jesus lived out the identity of one who was totally committed to God's Rule and to the undivided loyalty to and love of both God and neighbor demanded by it, and paid dearly for this singular commitment. As Fiorenza writes:

The gospels relate that precisely because of his life-praxis, his double solidarity, Jesus was condemned and executed. Since both the religious and political leaders played a role in his death, it would be inadequate to attribute his death mainly or solely to the responsibility of the one over the other, the self-identity expressed in his life-praxis must have offended both authorities. It was not his proclamation of superiority to the law alone. Nor was it merely his preaching of the kingdom that might have been understood in terms of possible zealot overtones. Instead it was precisely his lifepraxis as a totality, his radical solidarity expressed in his communicative words and actions, that lead [sic] to his death. ${ }^{70}$

His proclamation of the Basileia, thus, was a message of an allembracing divine emancipatory solidarity that offended the unjust power structures of his day, both religious and political.

In a world of human sin and injustice, such a message of solidarity can only be met with violent opposition. Not only does the cross determine Jesus's self-identity in terms of his twofold solidarity, but it is at once both the testimony and consequence of a double commitment lived to the death. Such a life can only lead to vindication. Therefore, Jesus's

\footnotetext{
68 Ibid., 104.

${ }^{69}$ See ibid.

70 Ibid.
} 
resurrection is not a reversal of the penalty suffered by Jesus for a sinful humanity, but a validation of his unconditional commitment to both God and humankind in the face of rejection. ${ }^{71}$

The redemptive life and death of Jesus renders present a solidarity, an "at-oneness," that confronts and emancipates us from sin and alienation, including the systematic frustration of human well-being prevalent in today's social structures. All forms of oppression, then, individual or social, can be viewed as the great divide that separates us from God and one another. Jesus as "Emmanuel," therefore, redeems us precisely by being with us to emancipate us from alienation in whatever form it may appearmeaninglessness, guilt, death, or social and structural evil.

As emancipatory solidarity, redemption, then, at once atones and redeems, reconciles and saves. Jesus's life bespeaks a saving divine presence immersed in the travails of human history. ${ }^{72}$ In his whole existence, in everything he said and did, Jesus pointed to and communicated the saving Reign of God-the great symbol for God's redemptive presence in the world. Jesus in his humanity proclaimed with prophetic indignation and demonstrated with power, the Reign of God that continues to confront the evils of sin and death in the world. ${ }^{73}$

\section{Filipino Christologies from the Standpoint of Emancipatory Solidarity}

If a largely individualistic understanding of redemption prevails, then justification can only mean the salvation of the individual soul, and not of humanity. An almost mechanical view of salvation, which automatically dispenses heavenly reward simply by virtue of Christ's sacrifice of himself to avert humanity's damnation, reinforces the view commonly expressed by Filipino Catholics that one can find hope, inspiration, meaning, and-

\footnotetext{
${ }^{71}$ Ibid., 106.

${ }^{72}$ Fiorenza, "Redemption,” 850. Cf. Fiorenza, "Critical Social Theory and Christology,” 109.

73 See Fiorenza, "Critical Social Theory and Christology," 110.
} 
ultimately-deliverance, not in Christ's moral exhortations nor in the powerful witness of his life, but in his sacrificial death alone. Thus the typical Filipino Catholic is routinely branded as a "split-level Christian," since there is in the typical pious Filipino believer a seeming incongruence between belief and witness. ${ }^{74}$ Such disparity comes as a result of a failure to see and appreciate the intrinsic value of making a personal and total commitment to Christ, whose moral program (vision, ideals, and teachings) for humanity - and not his sacrificial death alone-is key to its ultimate upliftment and redemption.

Isn't this a case of what critics of atonement theories call distorted ethical behavior resulting from inadequate or distorted theology? ${ }^{75}$ Doesn't the gap between religious devotion and ethical life come from an inordinate amount of attention given to a particular aspect of Christ's life-either his birth or death_and making it the sole criterion for salvation? Fiorenza's theology of emancipatory solidarity forces us to see that the death of Christ lifts us up, "atones" for our inadequacies, and redeems our humanity not as payment for an eternal debt that only a divine being could make, but as the culmination of a life of heroic moral virtue in relation to both God and neighbor. His resurrection is not a reward for the horrendous human ordeal of sacrificing innocent life for all. It is vindication of a life well lived - a life fully lived.

The perennial temptation in Filipino popular religious culture is to patronize Christ, not to follow and emulate his character and virtues. The two dominant Filipino images of Christ either patronize the Child Jesus, on the one hand, and the suffering victim, on the other. In the case of the former, he seems never to grow to real manhood. ${ }^{76}$ And on the other hand, by the time he does, the only way he can be relevant is to suffer and

\footnotetext{
${ }^{74}$ Elwood and Magdamo, Christ in Philippine Context, 10. See Jaime Bulatao, Split-Level Christianity (Manila: Ateneo University Press,1966), 21.

${ }^{75}$ See Daly, "Images of God and the Imitation of God: Problems with Atonement," 36.

${ }^{76}$ Elwood and Magdamo, Christ in Phillipine Context, 6.
} 
die. The disproportionate significance given to his suffering and death generally disregards the dynamic Christ of the Gospels-teacher, healer, wisdom figure, prophet- the exemplar of how it is to live a truly human life. ${ }^{77}$ The life and teachings of the man Jesus are overshadowed by practices of popular piety that involve either the Christ Child or the martyred Christ. ${ }^{78}$ And since the man Jesus is all but forgotten in a liturgical year that concentrates much of its moral exhortations on Christmas and Holy Week, a vacuum is indeed created that could have addressed the need for a more developed moral imagination and for an education with a sustained focus on the life and teachings of the man Jesus. ${ }^{79}$ This approach may in the process refocus rituals of popular religiosity toward a more integral and holistic Christian conversion and witness. Otherwise, the gap between Catholic faith and daily life shall always remain.

And yet, for all the obvious objections that can be raised against the excesses of popular piety, even its so-called critics concede that "on a topic as deep as the Christian theology of the cross, there can be no single exhaustive understanding." 80 The cross of Christ discloses a powerful image of salvation from sin that eludes systematic theological inquiry, and yet, continues to inform Christian ritual and worship. ${ }^{81}$ And it is precisely this revelatory, profoundly evocative potential that makes "the cross a powerful religious symbol of suffering humanity, even for many who are oppressed by other Christians and who look to Christ as their liberator, a symbol that indeed inspires their resistance." 82

\footnotetext{
${ }^{77}$ Ibid., 7.

78 Alan J. Delotavo, "Images of Christ in Filipino Culture and Atonement Experiences," Asia Journal of Theology 15, no. 1 (April 2001): 146.

${ }^{79}$ Delotavo suggests a more Christ-centered preaching in the parish. See ibid., 148.

${ }^{80}$ Haight, The Future of Christology, 76.

${ }^{81}$ Cahill, The Atonement Paradigm, 425.

82 Ibid.
} 
It may come as a surprise, therefore, that the Pasyon, which has traditionally extolled the virtues of docility and quiet suffering, provided the cultural framework for scattered social upheavals during the Spanish period. When religion wed-and exploited-local culture in the Philippines as part of the oppressive state apparatus, the same faith ironically gave many Filipinos a template for resistance against its colonial masters. ${ }^{83}$ Beltran explains:

While the Christology from above can foster passivity and acceptance of things as they are, Filipino rebellions which were motivated by religious reasons have shown that the descending approach can also promote the questioning of the apparent givenness of things in the light of the belief in the absoluteness of divine authority. The traditional approach might have fostered the unquestioning acceptance of the givenness of the colonial structure during the period of Spanish domination. Nevertheless, we have seen that the reading of the Pasyon opened the minds of Filipinos to the relativism of all authority other than the divine. They aligned themselves to a vision which anticipated the judgment of God as revealed in Christ. ${ }^{84}$

The Pasyon, hence, was not merely a narrative about the Second Person of the Trinity who in his incarnation as man had to suffer and die to once again open the gates of the Kingdom for a damned humanity. ${ }^{85}$ "The suffering Christ became an example par excellence for the Filipino who wanted to resist." $" 86$

\footnotetext{
83 Gabriel Tan, "Review of Pasyon and Revolution," October 2, 2012, http:// www.goodreads.com/review/show/428648604, accessed October 25, 2013.

${ }^{84}$ Beltran, Christology of the Inarticulate, 218-19.

85 Tan, "Review of Pasyon and Revolution."

86 Ibid.
} 
Far from becoming an opiate to deaden the consciousness to human suffering by anticipating a paradise in the hereafter, religious faith had become key in the struggle for emancipation from oppression and human misery. ${ }^{87}$ Just as the struggle and crucifixion of Christ would culminate eventually in his victory over death, the struggle against the yoke of Spanish oppression was seen by the popular peasant movements as the Motherland's journey from slavery to liberation, couched in the Pasyon's "powerful images of transition: darkness to light, despair to hope, misery to salvation, death to life." 88 The revolutionary movement saw in suffering the inevitable cost of liberation. It was this belief that sustained their spiritual fortitude. 89

Cahill suggests that "if resistance and liberation are potential moral outcomes of an atonement paradigm that includes cross and sacrifice," the Resurrection is that final element that completes this potential. ${ }^{90}$ Not only do the death and resurrection of Christ constitute one redeeming event as the New Testament kerygma consistently proclaims (1 Cor. 15:3-4), it is precisely so because, as Fiorenza points out emphatically, the Resurrection is not the reward for but the validation of Christ's redemptive life of deep solidarity with both God and suffering humanity.

\section{A Conclusion}

Jesus paid the price of his life for a commitment that affirmed both his profound union with God and his compassionate solidarity with suffering humanity. Jesus died not as someone marked out for death by God in exchange for the retribution that a rebellious humanity so justifiably deserved, but as a consequence of a radically challenging message of divine emancipatory solidarity that upset the power structures of his day.

\footnotetext{
${ }^{87}$ Ibid.

${ }^{88}$ Ileto, Pasyon and Revolution, 18. Cf. Tan, "Review of Pasyon and Revolution."

${ }^{89}$ See Tan, "Review of Pasyon and Revolution."

90 Cahill, The Atonement Paradigm, 425. Unfortunately, it is the resurrection that is least recognized and celebrated in much of popular religious literature, rituals of pious religiosity, and liturgical re-enactments.
} 
Though not an end in itself, human suffering freely embraced can be viewed as the cost of one's ongoing commitment to Gospel values, as made evident in the Beatitudes (Mt. 5:6, 10-11). This not only recognizes the centrality of Christ's resurrection to the Christian Faith, but also the truly redemptive power of his very life and ministry of healing the sick and driving out oppressive spirits, of comforting the inconsolable, and embracing both the outcasts and the un-forgiven, of breaking bread with the people, and giving the poor and the misunderstood God's special unconditional regard. All this offered the gracious presence of God, no less. The failure to see the redemptive, reconciling and healing hand of God in Christ's life, ministry, and resurrection may result precisely in the kind of distorted understanding of divine justice (or retribution) that God metes out punishment for humanity's offenses in the form of suffering, or requires the sacrifice of an innocent life as ransom payment for sin.

"Though [Christ] was in the form of God, he did not deem equality with God something to be grasped at. Rather, he emptied himself and took the form of a slave, . . . and it was thus that he humbled himself, obediently accepting even death on a cross" (Phil 2:6-8). This divine solidarity with humanity is an image that gives consolation and hope to "the poor and disadvantaged [who] respond by instinct to this identification." 91 Is it because their disadvantaged social circumstances make them see the Cross-more than any other symbol_as a healing, reassuring sign of divine solidarity with their personal sufferings? After all, the poor-they only see the Crucifixion. It is everywhere. It is all there is. ${ }^{92}$ Are we who claim to be theological sophisticates in a position to judge their images and rituals to be adulterated expressions of faith? What we may consider with derision as an inarticulate crowd of worshippers' bizarre devotion may be in truth their only access to faith and hope in a world that has so deprived them of the same. While this may have encouraged the kind of passivity in

\footnotetext{
${ }^{91}$ Philip Yancey, "Surveying the Wondrous Cross: Understanding the Atonement is About More Than Grasping a Theory," Christian Today (May 2009): 72.

92 Ibid.
} 
the face of suffering so characteristic of Filipino piety, Philippine history bears witness to the real possibility that the image of the hero-martyr-in the Pasyon or in the martyred Benigno Aquino, Jr. ${ }^{93}$ — may spark the kind of "revolution" that anticipates the salvation in the hereafter by embracing, overcoming, saving-indeed, redeeming - the sinfulness, the dislocation, the injustice and oppression of the present.

\section{Epilogue}

On the last year of his public ministry, a Jewish itinerant preacher-a man wildly popular, if not notorious, in his time-mounted a colt and went up to Jerusalem to celebrate the Jewish Passover-a feast commemorating Jewish liberation from Egyptian oppression. In the great tradition of the Hebrew prophets, this preacher challenged the brokerage function of the revered Jewish Temple priesthood, unnerved the Romanbacked Jewish establishment, ${ }^{94}$ and triggered for himself a quick succession of events that would lead inevitably to the fate of any Old Testament prophet.

Death (a brutal one under his Roman executioners), however, was not the end of the story for this peasant politico-religious agitator. His closest associates continued to speak not only of affectionate loyalty to him and his cause, but also of a resurrection ${ }^{95}$ — clearly a divine vindication, a recognition of the uninterrupted, abiding divine presence at work throughout his life of service and witness that was at once atoning and redemptive, not only for the sins of Israel, but for the whole world as well.

\footnotetext{
${ }^{93}$ Benigno S. 'Ninoy' Aquino, Jr. (1932-1983) was the chief political rival of then President Ferdinand E. Marcos (1917-1989). His assassination in August 21, 1983 led to a series of public demonstrations calling for the resignation of high-ranking public officials responsible for the security of Aquino, including Marcos himself. This pressured Marcos to hold early presidential elections to regain public confidence. However, the massive fraud which marred the snap elections sparked a nationwide protest movement. This culminated in the Bloodless EDSA Revolution of February 1986. Ninoy Aquino was husband to Corazon C. 'Cory' Aquino (1933-2009), herself an icon of Philippine democracy, and father to Benigno Simeon 'Noynoy' Aquino, III, 15th president of the Republic of the Philippines.

${ }^{94}$ See John Dominic Crossan, Jesus: A Revolutionary Biography (New York: Harper Collins, 1994), 197.

${ }^{95}$ See ibid., 198.
} 


\section{Bibliography}

Asis, Michael Demetrius H. "Hermeneutical Theory and the Quest for the Historical Jesus: A Study of Two Christologies." The Loyola Schools Review 1 (2001): 95-107.

Beltran, Benigno P., The Christology of the Inarticulate: An Inquiry into the Filipino Understanding of Jesus the Christ. Manila: Divine Word Publications, 1987.

Biema, David Van. “Why Did Jesus Die?” Time, April 12, 2004.

Bulatao, Jaime. Split-Level Christianity. Manila: Ateneo University Press, 1966.

Bultmann, Rudolf. Jesus Christ and Mythology. New York: Charles Scribner's Sons, 1958.

Theology of the New Testament. Translated by K. Grobel. New York: Charles Scribner's Sons, 1951.

Cahill, Lisa Sowle. "Quaestio Disputata The Atonement Paradigm: Does It Still Have Explanatory Value?” Theological Studies 68 (2007): 418-32.

Catholic Bishops' Conference of the Philippines (CBCP). The Acts and Decrees of the Second Plenary Council of the Philippines. Manila: CBCP Secretariat, 1992.

Chauvet, Louis-Marie. Symbol and Sacrament: A Sacramental Reinterpretation of Christian Existence. Translated by Patrick Madigan and Madeleine Beaumont. Collegeville, PA: Liturgical Press, 1995.

Crossan, John Dominic. Jesus: A Revolutionary Biography. New York: HarperCollins, 1994.

Daly, Robert J. "Images of God and the Imitation of God: Problems with Atonement" Theological Studies 68 (2001): 36-51.

Delotavo, Alan J. "Images of Christ in Filipino Culture and Atonement Experiences." Asia Journal of Theology 15, no. 1 (April 2001): 140-50.

De Mesa, Jose M. and Lode L. Wostyn. Doing Christology: The Re-Appropriation of a Tradition. Quezon City: Claretian Publications, 1989.

Elwood, Douglas J. and Patricia L. Magdamo. Christ in Philippine Context. Quezon City: New Day Publishers, 1971.

Episcopal Commission on Catechesis and Catholic Education (ECCCE). Catechism for Filipino Catholics. Manila: Word \& Life Publications, 1997.

Catechism of the Catholic Church. Vatican: Libreria Editrice Vaticana, 1994. Reprint, Manila: Word \&Life Publications, 1994.

Fiorenza, Francis Schüssler. "Critical Social Theory and Christology: Toward an Understanding of Atonement and Redemption as Emancipatory Solidarity." Proceedings of the Catholic Theological Society of America 30 (1975): 63-110. 
" "Redemption." In The New Dictionary of Theology, edited by Joseph A. Komonchak, Mary Collins, and Dermot A. Lane, 836-51. Pasay City: St. Paul Publications, 1991.

Fitzmyer, Joseph A. "Pauline Theology." In The New Jerome Biblical Commentary, 2nd ed., edited by Raymond E. Brown, Joseph A. Fitzmyer, and Roland E. Murphy, 1382-416. Quezon City: Claretian Publications, 1993.

Francisco, Jose Mario C. "Christian Symbols and Rituals in Philippine Society." Pulso 7 (June 1991): 16-25.

Gadamer, Hans-Georg. Truth and Method. Revised 2nd ed. Translated by Joel Weinsheimer and Donald Marshall. New York: Sheed \& Ward, 1989.

Haight, Roger. Dynamics of Theology. New York: Paulist Press, 1990.

Ihde, Don, ed. "Editor's Introduction." In The Conflict of Interpretations: Essays in Hermeneutics, ix-xxv. Evanston: Northwestern University Press, 1974.

Ileto, Reynaldo C. Pasyon and Revolution: Popular Movements in the Philippines, 1840-1910. Quezon City: Ateneo de Manila Press, 1979.

Kümmel, Werner. The Theology of the New Testament. Translated by J. E. Steely. New York-Nashville: Abingdon Press. 1973.

McBrien, Richard P. Catholicism. Revised and enlarged 3rd ed. New York: Harper Collins, 1994. Reprint, London: Geoffrey Chapman, 2000.

Moloney, Francis J. "Johannine Theology.” In The New Jerome Biblical Commentary, 1417 26.

Moltmann, Jürgen. The Crucified God: The Cross of Christ as the Foundation and Criticism of Christian Theology. Translated by R. A. Wilson and J. Bowden. New York: Harper and Row, 1974.

Le Dieu crucifié: La croix du Christ, fondement et critique de la théologie cbrétienne. Paris: Cerf, 1974.

Pannenberg, Wolfhart. Jesus_God and Man. Translated by L. L. Wilkins and D. A. Priebe. Philadelphia: Westminster Press, 1968.

Rahner, Karl. Theological Investigations. Vol. 1. Translated by K. Smyth. New York: Seabury, 1974.

"Salvation." In Sacramentum Mundi, vol. 2, 405-38. New York: Herder and Herder, 1970,

Ricoeur, Paul. "Existence and Hermeneutics." Translated by Kathleen McLaughlin. In The Conflict of Interpretations, 3-24.

"The Problem of Double Meaning." Translated by Kathleen McLaughlin. In The Conflict of Interpretations, 62-78. 
Tan, Gabriel. "Review of Pasyon and Revolution." October 6, 2012. http:// www.goodreads.com/review/show/428648604. Accessed October 25, 2013.

Yancey, Philip. "Surveying the Wondrous Cross: Understanding the Atonement is About More Than Grasping a Theory." Christian Today (May 2009): 72. 